\title{
Regulation of transgenes in three-dimensional cultures of primary mouse mammary cells demonstrates oncogene dependence and identifies cells that survive deinduction
}

\author{
Martin Jechlinger, ${ }^{1}$ Katrina Podsypanina, and Harold Varmus \\ Program in Cancer Biology and Genetics, Sloan Kettering Institute, Memorial Sloan-Kettering Cancer Center, New York, \\ New York 10065, USA
}

The advent of targeted therapies for cancer has provoked interest in experimental models for the systematic study of oncogene dependence. To that end, we developed a three-dimensional (3D) culture system to analyze the responses of primary mouse mammary epithelial cells to the induction and deinduction of oncogenes. Mammary cells derived from normal virgin mice, or from tritransgenic mice (TetO-MYC;TetO-Kras ${ }^{\text {G12D }}$;MMTV-rtTA) in which $M Y C$ and mutant Kras can be regulated by doxycycline, develop from single cells into polarized acini. Lumen formation occurs without apparent apoptosis, and the hollow spheres of cells enlarge by division, with metaphase plates oriented perpendicularly to the apical surface. When MYC and Kras ${ }^{G 12 D}$ are induced, the acini enlarge and form solid, depolarized spheres. Upon deinduction of $M Y C$ and $K r a s{ }^{G 12 D}$ the solid structures regress, leaving a repolarized monolayer of viable cells. These cells display a phenotype consistent with progenitors of mammary epithelium: They exclude Hoechst dye 33342, and reform acini in 3D cultures and repopulate mammary fat pads more efficiently than cells harvested from uninduced acini. Moreover, cells in the surviving spheres retain the ability to respond to reinduction and thus may represent the type of cells that give rise to recurrent tumors.

[Keywords: Oncogene dependence; primary cells; mammary gland; three-dimensional culture; residual tumor cells; inducible transgenes]

Supplemental material is available at http://www.genesdev.org.

Received March 19, 2009; revised version accepted May 28, 2009.

Extensive evidence now supports the concept of oncogene dependence (or "oncogene addiction"): In patients with certain cancers, in several mouse models of human cancer, and in some cancer cell lines, interference with the expression or activity of cancer-initiating oncogenes can cause tumor regression (Chin et al. 1999; Felsher and Bishop 1999; Druker et al. 2001; Fisher et al. 2001; Weinstein 2002; Varmus et al. 2005). However, novel therapies that target the products of mutant alleles in human cancers are only partly successful, since maintenance of remission requires long-term treatment and relapses often occur in the presence of therapeutic agents. Hence, better understanding of drug resistance and tumor recurrence is needed for the design of more successful anti-cancer strategies.

${ }^{1}$ Corresponding author.

E-MAIL jechlinm@mskcc.org; FAX (646) 888-3010.

Article is online at http://www.genesdev.org/cgi/doi/10.1101/gad.1801809.
Oncogene dependence has been demonstrated frequently with transgenic mouse models in which oncogenes are conditionally expressed in specific cell types, usually under the control of tetracycline-responsive transcriptional regulators (Druker et al. 2001; Fisher et al. 2001; Moody et al. 2002; Weinstein 2002; Gunther et al. 2003; Shachaf et al. 2004; Podsypanina et al. 2008). In such genetically engineered animals, induction of oncogenes initiates development of tumors over weeks or months, while deinduction of the tumor-initiating oncogenes then mimicks treatment with an ideally targeted drug, usually causing rapid regression of the tumors. Such models provide tractable systems for studying the mechanisms of oncogene dependence, the response and resistance to targeted drugs, and tumor recurrence. But studies conducted with transgenic animals are slow, expensive, and often too complex to reveal detailed mechanistic insights. This prompts interest in culture methods that can be used to study oncogene dependence 
with respect to cellular organization and position of specialized cells within a tumor.

With this goal in mind, we adapted three-dimensional (3D) cell culture methods to study the behavior of primary mouse mammary epithelial cells in response to the induction and deinduction of conditionally regulated oncogenes. 3D culture systems represent an important means to study the impact of oncogenic mutations on specific aspects of the neoplastic phenotype, since they can recapitulate organotypic growth with respect to a polarized phenotype, specialized cell-cell contacts, and attachment to an underlying basement membrane (Schmeichel and Bissell 2003; Debnath and Brugge 2005). All of these features are necessary for the proper control of cellular proliferation, survival, and differentiation.

Prior efforts to develop 3D culture systems to study neoplasia generally have used immortalized cell lines from various lineages: MDCK cells (Hall et al. 1982; Montesano et al. 1991), EpH4 cell series (Reichmann et al. 1992; Grunert et al. 2003), MCF10A cells (Schmeichel and Bissell 2003; Debnath and Brugge 2005), and HMT3522 cell series (Weaver et al. 1995). These organotypic cultures have helped to identify biochemical mechanisms and biological behavior important for mammary tumor development and progression (Reichmann et al. 1992; Weaver et al. 1995; Bissell and Radisky 2001; Debnath et al. 2002; Debnath and Brugge 2005). However, the mutational status and the cellular origin of established epithelial cell lines remain uncertain (Reichmann et al. 1989; Soule et al. 1990).

As an alternative, primary mammary cells have been cultivated successfully on a reconstituted basement membrane matrix to develop into hollow acini that are sealed by tight junctions (Hamamoto et al. 1988; Barcellos-Hoff et al. 1989; Petersen et al. 1992). Using similar 3D cultures of primary mammary cells, we observed the rapid formation of polarized hollow acini in the absence of oncogenic signals. When oncogenes are induced, these acini develop into solid spheres of rapidly growing cells that have lost epithelial polarity. Upon oncogene deinduction, the internal cells undergo apoptosis, leaving an outer layer of repolarized cells. The surviving cells display several properties of mammary gland progenitors and may represent cell culture analogs of cells that give rise to recurrent tumors.

\section{Results}

Growth of primary mammary cells in $3 D$ cultures produces acini composed of polarized cells

To study the effects of oncogene induction and deinduction on primary mammary epithelial cells in culture, we sought to grow the cells in a manner that resembles growth in the animal. As a first step, we seeded single cells derived from the mammary gland of 6-to 8-wk-old, virgin, nontransgenic mice into a $3 \mathrm{D}$ matrix containing Collagen I intermixed with laminin 1-rich Basement Membrane Extract. This combination has previously been used to grow human mammary luminal epithelial cells as acini with correctly polarized apical and basal surfaces (Gudjonsson et al. 2002; Schmeichel and Bissell 2003). After seeding of the mammary cells, a substantial fraction $[8.4 \% \pm 0.6 \%$ in the eight gels analyzed $(8000$ cells/100 $\mu \mathrm{L}$ gel)] formed microscopic colonies. The lumen was first visible as early as $36 \mathrm{~h}$ after seeding, when the colonies contain six to eight cells (Fig. 1A [top panels], C,D [bottom panels]); subsequent cell divisions appeared to enlarge the acinus significantly over the next $24 \mathrm{~h}$ (Fig. 1A, bottom panels; Supplemental Movie S1). Similar findings were observed with at least four acini followed by time-lapse microscopy, indicating that the kinetics of growth and lumen formation are similar in most colonies.

We then used immunostaining and confocal microscopy to determine the presence and location of proteins that serve as markers of epithelial cell polarity. These experiments revealed that the acini are composed of polarized cells in the correct orientation, with the apical surface juxtaposed to the lumen. Integrin $\alpha 6$ was located at the basolateral surface, as expected, in a pattern that does not overlap with the location of Zona Occludens-1 (ZO1), a protein that directly binds to occludins and marks tight junctions (Fig. 1B). The acini had distinct adherens junctions as visualized by lateral epithelial cadherin (E-Cadherin) (Fig. 1B).

Formation of hollow acini depends on the orientation of the mitotic plate in dividing cells, rather than apoptosis of internal cells

Proliferating mammary cells in 3D cultures maintained their apical regions oriented exclusively toward the center of the sphere, as detected by staining for the apical submembranous marker atypical-PKC (aPKC) (Izumi et al. 1998) and ZO1 (Fig. 1C,D). Interestingly, an apical patch was visible as early as the two-cell stage (Fig. 1C,D, top rows), in line with findings reported recently for 3D growth of the human intestinal cell line, Caco2, that is used to study epithelial morphogenesis (Jaffe et al. 2008). At the six- to eight-cell stage, growing polarized acini contained a lumen that was lined by the apical marker aPKC (Fig. 1C, bottom row) and the tight junction marker ZO1 (Fig. 1D, second row).

This early polarized epithelial phenotype is most easily explained if, as cells divide, the axis of the mitotic spindle is oriented parallel to the luminal surface, giving rise to two daughter cells with the same polarity. Indeed, both sets of chromosomes in a dividing cell were oriented perpendicular to the ZO1-lined apical surface (Fig. 2A). $3 \mathrm{D}$ reconstruction of confocal images confirmed that the metaphase plate was perpendicular to the apical surface in all structures analyzed, even at time points as early as the second cell division $(N=12)$ (for further examples, see Supplemental Figs. S1A,B, S2A-D). This simple mechanism, to produce an apical/basal cleavage plane for maintaining the integrity of apical membrane structures during cell division, has also been observed in the mouse intestine in vivo (Fleming et al. 2007) and in 3D cultures of Caco2 cells (Jaffe et al. 2008). 
A

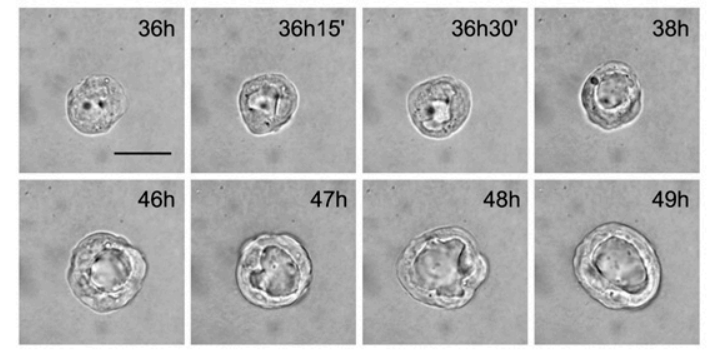

B

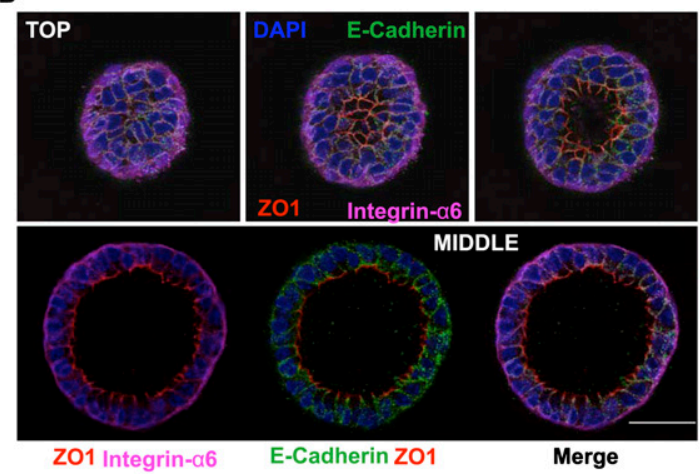

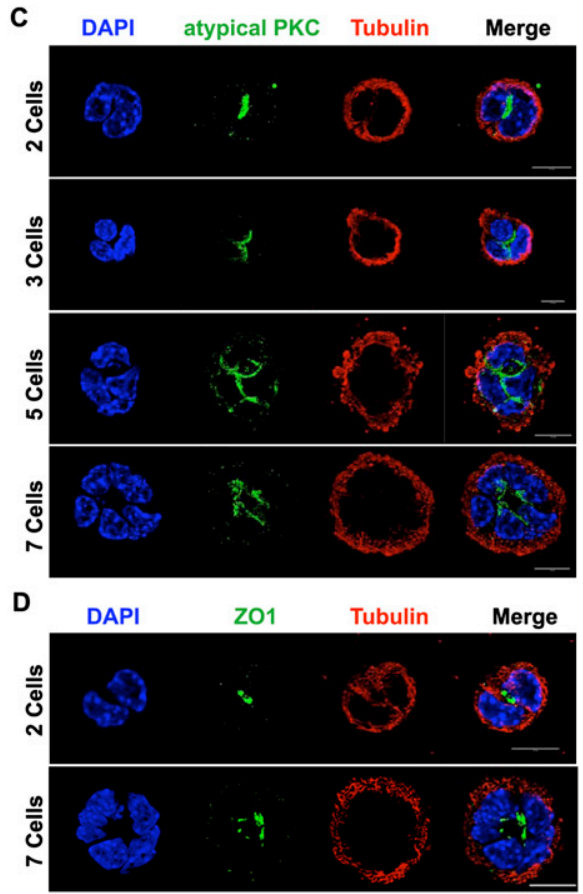

Figure 1. Nontransgenic primary mammary cells grown in $3 \mathrm{D}$ cultures develop acini composed of polarized epithelial cells. $(A)$ Pictures taken every $15 \mathrm{~min}$ using a bright-field microscope show a typical colony of mammary cells derived from nontransgenic mice develop into an acinus at the indicated time points. Bar, $10 \mu \mathrm{m}$. (B) Confocal microscopy demonstrates epithelial cell polarity in a single large acinus. Each panel projects 25 subsequent confocal images (covering $5 \mu \mathrm{m}$ ). (Top panels) Three adjacent sections from the top of the acinus (15 $\mu \mathrm{m}$ total). (Bottom panels) Five-micron projection through the middle of the acinus. (Blue) DAPI stain; (green) E-Cadherin (adherent junctions, lateral); (red) ZO1 (tight junctions, apical); (magenta) Integrin $\alpha 6$ (basolateral). Bar, $30 \mu \mathrm{m}$. (C) Confocal microscopy localizes the apical marker aPKC to the peri-luminal region. The figure shows projection of 20 confocal image layers (each covering 4 $\mu \mathrm{m}$ in total). (Top panels) Two-cell stage. (Second row) Three-cell stage. (Third row) Five-cell stage. (Bottom row) Seven-cell stage. (Blue) DAPI stain; (green) aPKC; (red) $\beta$-tubulin. Bar, $10 \mu \mathrm{m}$. (D) Confocal microscopy after staining with anti-ZO1 antiserum identifies the tight junction protein ZO1 at the center of the spheres. Each panel shows 20 confocal images (covering $4 \mu \mathrm{m}$ total) through the middle of an acinus. (Top panels) Two-cell stage. (Bottom panels) Eight-cell stage. (Blue) DAPI stain; (green) ZO1; (red) $\beta$-tubulin. Bar, $10 \mu \mathrm{m}$.

As noted earlier, primary mouse mammary cells have been grown successfully in a reconstituted basement membrane matrix to form hollow acini sealed by tight junctions (Barcellos-Hoff et al. 1989). The mechanism that establishes such hollow acini in 3D cultures of mammary cells, however, has been studied only with the human mammary epithelial cell line MCF10A; these cells generate hollow structures through the loss of internal cells by apoptosis and autophagy (Debnath and Brugge 2005), phenomena not observed in our cultures. DAPI staining and confocal microscopy did not reveal cells at the centers of acini, even in those just beginning to form lumina (Fig. 1B-D, bottom panels). We also failed to detect activated caspase-3, a marker for apoptosis, when cells were grown in the presence of a caspase-3cleavable fluorescent dye (NucView substrate). For example, no caspase- 3 activity was detected in a typical growing acinus with a ZO1-lined lumen $48 \mathrm{~h}$ after seeding (Fig. 2B, top left); in contrast, one of the few collapsing aggregates of unpolarized cells that can be found in a gel stained brightly for active caspase-3 (Fig. 2B, bottom right). Taken together, our data suggest that primary mammary cells in 3D cultures form a lumen without apoptosis, as reported in diverse epithelial tissues (Lowery and Sive 2005; Husain et al. 2006; Bagnat et al. 2007; Tsarouhas et al. 2007) and for the Caco2 cell line in 3D cultures (Jaffe et al. 2008).

\section{Acini composed of cells from}

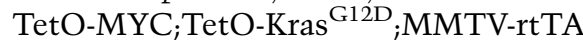

(tritransgenic) mice respond to oncogene induction

Cells obtained from the mammary glands of 6- to 9-wkold, virgin, doxycycline-naïve TetO-MYC;TetO-Kras ${ }^{\text {G12D }}$; $M M T V-r t T A$ (tritransgenic) mice formed polarized acini identical to nontransgenic (normal) primary mammary cells (Figs. 3C [top left panel], 4A [right panels]). We harvested RNA from acini before, during and after doxycycline treatment (for exact times, see the legend for Fig. 3A), and monitored expression of MYC and Kras ${ }^{G 12 D}$ transgenes in 3D culture by RT-PCR (Fig. 3A). Within $18 \mathrm{~h}$ after addition of doxycycline, the wall in each acinus began to thicken until the lumen was nearly completely obscured after $48-130 \mathrm{~h}$ (Fig. 3B,C, top panels; Supplemental Movie S2, 18-40 h). This behavior upon doxycycline exposure is strikingly similar in kinetics and appearance to that of hollow ducts that become hyperplastic in tritransgenic animals (Fig. 3C, bottom panels; Podsypanina 
Jechlinger et al.

Figure 2. Primary mammary cells orient their mitotic spindle perpendicular to an apical surface and form a lumen without involvement of apoptotic mechanisms. (A) Orientation of cell division in an expanding polarized acinus that is grown from primary nontransgenic mammary cells. One cell in anaphase is dividing with the two sets of chromosomes perpendicular to the apical surface, while keeping ZO1 localized to the luminal membrane; three adjacent projections ( $4 \mu \mathrm{m}$ each) cover the center region of the sphere. (Top left panel) bottom projection. (Top right panel) Middle projection. (Bottom left panel) Top projection. The bottom right panel depicts the situation in a graphical sketch. (Blue) DAPI stain; (green) ZO1; (red) $\beta$-tubulin. Bar, $20 \mu \mathrm{m}$. (B) Confocal image of spheres that were grown from nontransgenic primary mammary cells, incubated with NucView

A
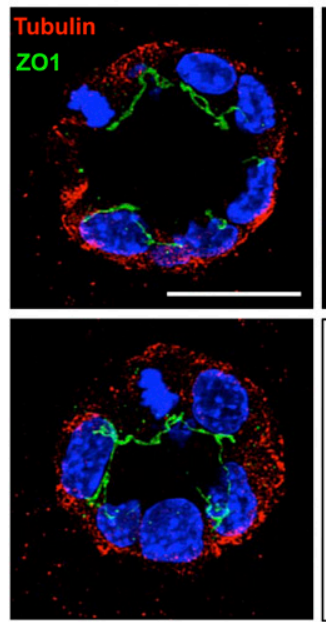

B
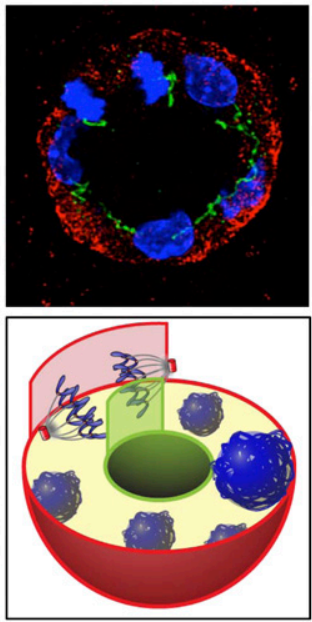

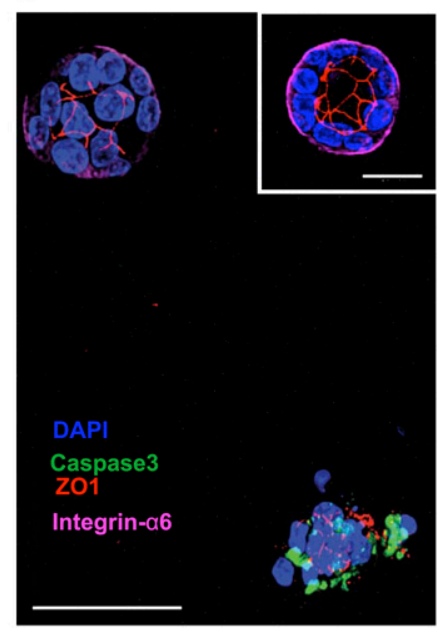

substrate-a cell membrane-permeable fluorogenic $(488 \mathrm{~nm})$ substrate-before seeding into 3D gels. Gels were fixed $60 \mathrm{~h}$ after cell seeding. (Top left corner) Acinus displaying an intact lumen is negative for caspase 3 and shows localized apical ZO1 (red) and basal Integrin $\alpha 6$ (magenta) staining. The insert shows $10-\mu \mathrm{m}$ projection for better appreciation of the lumen.Bar, $20 \mu \mathrm{m}$. (Bottom right corner) Collapsed structure of cells displays green fluorescent cleaved substrate (no localized ZO1 and Integrin $\alpha 6$ staining). (Blue) DAPI staining; (green) NucView; (red) ZO1; (magenta) Integrin $\alpha 6$ (80- $\mu \mathrm{m}$ projection). Bar, $40 \mu \mathrm{m}$.

et al. 2008). These observations with the tritransgenic cells in a $3 \mathrm{D}$ matrix are also reminiscent of changes observed after expression of ErbB2 or Raf oncogenes in MCF10A cells, which have been used to model ductal carcinoma in situ (DCIS) (Muthuswamy et al. 2001; Pearson and Hunter 2007).

Loss of normal tissue organization is an early diagnostic feature of DCIS (Porter et al. 2003; Burstein et al. 2004). To investigate the structural organization of the solid spheres observed in our cultures following oncogene induction, we followed the distribution of polarization markers by confocal microscopy. As shown in Figure 4A (top left panel), the apical marker GM130 was randomly distributed throughout the doxycycline-induced sphere, in contrast to its restriction to the apical location in acinar cells not exposed to doxycycline (Fig. 4A, top right panel). Similarly, the basal marker Integrin $\alpha 6$ stained the entire cell and was no longer restricted to a basal
Figure 3. Myc and $\mathrm{Kras}^{G 12 D}$ are regulated in response to doxycycline in $3 \mathrm{D}$ gels, and expression is associated with conversion of a hollow acinus to a solid sphere. (A) RTPCR for transgene-specific MYC and Kras ${ }^{G 12 D}$ expression. RNA was harvested from cells that were obtained from mammary glands of 6- to 9-wk-old, virgin, doxycycline-naïve TetO-MYC;TetO-Kras ${ }^{G 12 D}$;MMTV-rtTA mice (tritransgenic cells). (First lane) Tritransgenic cells grown in the absence of doxycycline for $18 \mathrm{~d}$. (Second lane) Tritransgenic cells grown $6 \mathrm{~d}$ in the absence of doxycycline and subsequently in the presence of doxycycline for $12 \mathrm{~d}$. (Third lane) Tritransgenic cells were grown $6 \mathrm{~d}$ in the absence of doxycycline, subsequently in the presence of doxycycline for $6 \mathrm{~d}$, and finally in the absence of doxycycline for $6 \mathrm{~d}$. (Top panel) Analyses for MYCspecific gene product. (Middle panel) Analyses for $\mathrm{Kras}^{\mathrm{G} 12 \mathrm{D}}$-specific gene product. (Bottom panel) $\beta$-actin control. (B) Pictures taken every 15 min using a brightfield microscope show a typical acinus grown from tritransgenic cells at indicated time points after doxycycline exposure. Bar, $30 \mu \mathrm{m}$. (C) H\&E staining on sections for harvested gels containing spheres grown from tritransgenic cells (top panels) and mouse mammary gland biopsies from tritransgenic animals (bottom panels) at indicated time points after exposure to doxycycline. Bars, $50 \mu \mathrm{m}$.

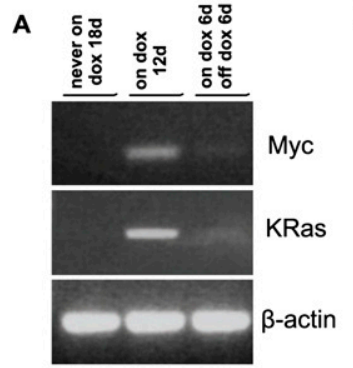

B
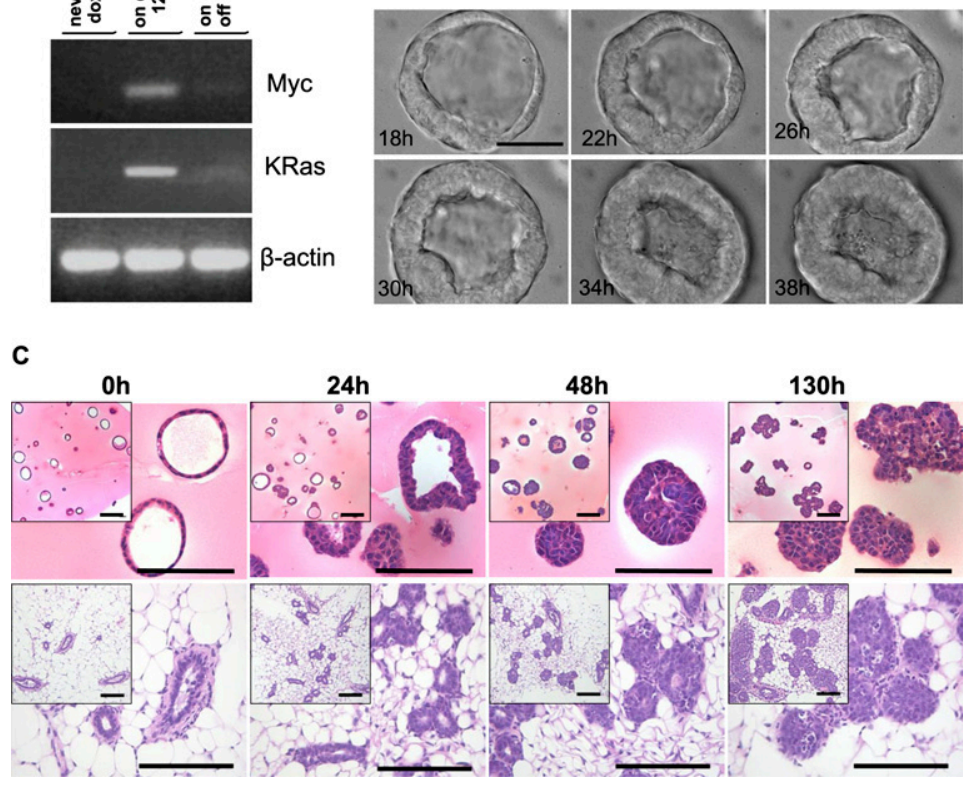
A

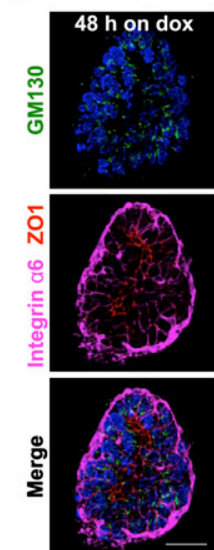

C

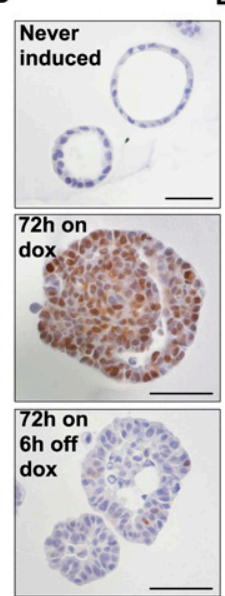

B

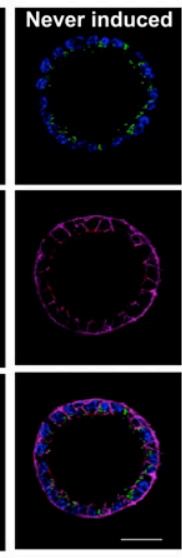

D
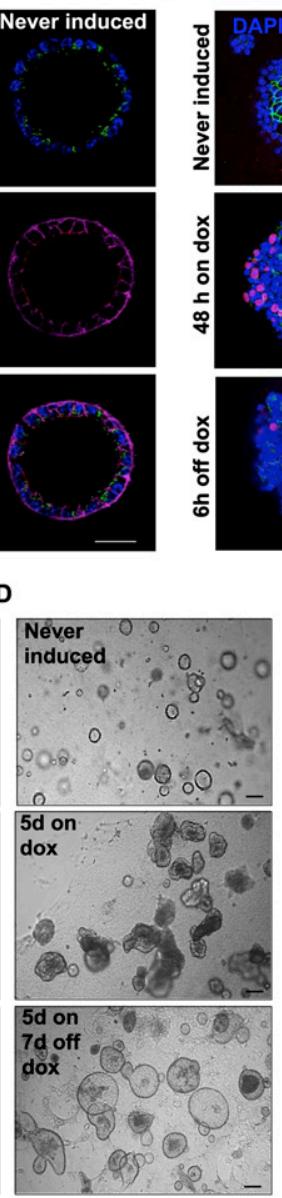
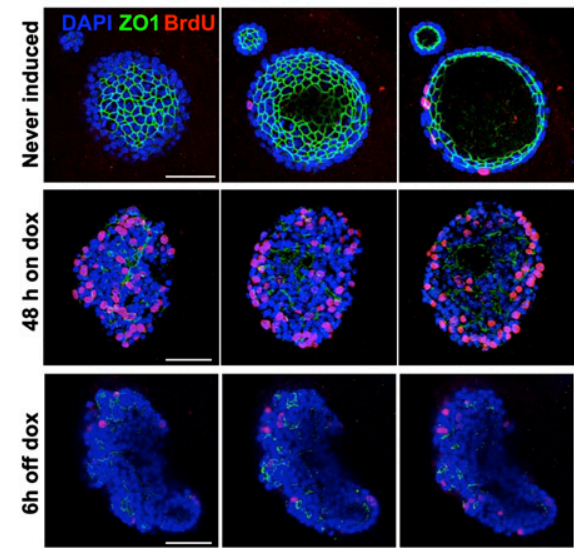

E

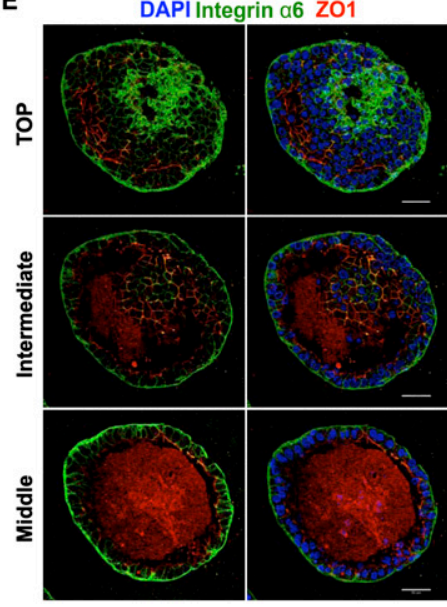

Figure 4. Doxycycline exposure causes loss of epithelial polarity and induces proliferation; weaning from doxycycline results in survival of a repolarized cell layer. (A) Confocal microscopy shows loss of epithelial cell polarity in an acinus grown from tritransgenic cells and exposed to doxycycline for 48 h. (Left panels) Five-micron projection through the middle of the sphere (doxycycline exposure $48 \mathrm{~h}$ ). (Right panels) Five-micron projection through the middle of an acinus that had never been exposed to doxycycline. (Blue) DAPI stain; (green) GM130 (Golgi protein, apical marker); (red) ZO1 (tight junctions, apical); (magenta) Integrin $\alpha 6$ (basolateral). Bar, 30 $\mu \mathrm{m}$. (B) Confocal microscopy shows high number of BrdU-incorporating cells in tritransgenic spheres exposed to doxycycline and lower number of BrdUincorporating cells for tritransgenic acini that were never induced with doxycycline or weaned from doxycycline. Three adjacent sections /covering $5 \mu \mathrm{m}$ each) for each doxycycline status are shown for a representative sphere; spheres were exposed to BrdU for $1 \mathrm{~h}$, before fixation. (Top panels) Polarized tritransgenic acinus that was never exposed to doxycycline. (Middle panels) Tritransgenic sphere exposed to doxycycline for $48 \mathrm{~h}$. (Bottom panels) Tritransgenic sphere exposed to doxycycline for $72 \mathrm{~h}$ and weaned from doxycycline for $8 \mathrm{~h}$. (Blue) DAPI stain; (green) ZO-1; (red) BrdU. Bar, $40 \mu \mathrm{m}$. (C) Pictures of immunostaining for Myc protein show regulation of the transgene tightly correlated to the doxycycline status of the spheres grown from tritransgenic primary mammary cells. (Top panel) Polarized acinus that was never exposed to doxycycline. (Middle panel) Sphere exposed to doxycycline for $72 \mathrm{~h}$. (Bottom panel) Sphere exposed to doxycycline for $72 \mathrm{~h}$ and weaned from doxycycline for $6 \mathrm{~h}$. Bar, $50 \mu \mathrm{m}$. (D) Bright-field pictures show a typical field with representative spheres grown from tritransgenic primary mammary cells. (Top panel) Hollow acini (grown without doxycycline for 18 d). (Middle panel) Filled, irregular-shaped spheres (cells grown into acini for $6 \mathrm{~d}$, then induced with doxycycline for $5 \mathrm{~d}$ ). (Bottom panel) Hollow, irregular-shaped spheres that show debris of internal cells (cells grown into acini for $6 \mathrm{~d}$, induced with doxycycline for $5 \mathrm{~d}$, and then deinduced for $7 \mathrm{~d}$ ). Bar, $50 \mu \mathrm{m}$. (E) Confocal microscopy shows a typical repolarized single-cell-layered sphere that survives doxycycline withdrawal. Tritransgenic primary mammary cells were grown into acini for $6 \mathrm{~d}$, induced with doxycycline for 5 d, and then grown without doxycycline for $7 \mathrm{~d}$. Three projections (covering $3 \mu \mathrm{m}$ of depth each) are shown. (Top) panels) Top level. (Middle panels) Intermediate level. (bottom panels) Sections through the middle of the sphere. (Blue) DAPI stain; (green) Integrin $\alpha 6$; (red) ZO1. Bar, $30 \mu m$.

compartment, as in polarized acini. Staining for ZO1 was not detected in the majority of cells, except for cells lining the small lumina outlined by ZO1 in the center of the sphere (Fig. 4A [left middle panel], B [middle panels]). At the same time, addition of doxycycline increased proliferation, as visualized by BrdU incorporation; a representative sphere exposed to doxycycline for $72 \mathrm{~h}$ is shown in Figure 4B (middle panels). Proliferating cells were also found in the middle of the solid sphere, an important feature since the continued growth and viability of cells in the absence of basement membrane contact are defining criteria of carcinomas. Within $8 \mathrm{~h}$ after removal of doxycycline from the growth medium, the numbers of BrdU-positive cells were reduced to those seen in polarized acini that had never been exposed to doxycycline (Fig. 4B, top and bottom panels). The withdrawal of doxycycline was also followed by a rapid decline in transgene-encoded protein as shown by immunostaining for MYC protein in sections from solid spheres harvested $6 \mathrm{~h}$ after doxycycline removal (Fig. 4C), presumably reflecting doxycycline-based regulation of transcription.

\section{Deinduction of MYC and Kras ${ }^{\mathrm{G} 12 \mathrm{D}}$ transgene expression leads to clearing of internal cells and survival of a repolarized layer of cells}

The rapid decline of oncogene expression and the proliferation arrest were associated with clearance of internal cells from the solid, irregularly shaped spheres (Fig. 4D, middle panel). Irregularly shaped hollow spheres survived, contained cell debris, and were significantly enlarged compared with acini that were never exposed to doxycycline (Fig. 4D, bottom panel). Remarkably, cells that survived oncogene withdrawal were organized in a single, repolarized layer of cells (Fig. 4E). Integrin $\alpha 6$ was exclusively found at the basal side of the irregularly 
shaped rim, and ZO1 lined a single large lumen that also contained autofluorescent cell debris (red) with embedded DNA detected by DAPI staining (Fig. 4E, bottom panels).

\section{Responses to doxycycline added to single cells rather than acini}

The experiments described thus far show the effects of adding doxycycline to mature polarized acini several days after seeding single cells in 3D cultures. When we added doxycycline to single tritransgenic cells at the time of seeding in the 3D matrix, the cells grew to form solid spheres directly, without an acinar phase. The solid spheres hollowed out following doxycycline withdrawal. These findings resemble the results observed after deinduction in experiments in which induction of oncogenes was delayed until polarized acinar structures were formed (Figs. 4, 5A). Immunostaining for GM130, ZO1, and Integrin $\alpha 6$ showed that solid spheres grown for $5 \mathrm{~d}$ after plating single cells in the presence of doxycycline were depolarized (Fig. 5B) and indistinguishable from solid spheres obtained by inducing polarized acini with doxycycline (Fig. 4A). Similarly, the single layer of cells that survived deinduction appeared polarized, as judged by the correct distribution of apical (GM130), basal (Integrin $\alpha 6$ ), and tight junction (ZO1) markers (Figs. 4E, 5C). Since similar single layers of surviving cells are obtained, regardless of whether the oncogenes were induced in a polarized acinus or in a single cell, we conclude that the determinants for cell survival upon shutdown of oncogenes are a consequence of cell placement at the time of deinduction, rather than polarization status or location in an acinus at the time of induction.

\section{Upon doxycycline withdrawal, internal cells lose mitochondrial polarity and undergo caspase-3-induced apoptosis}

To explore the mechanism by which internal cells are cleared after doxycycline withdrawal, we followed events occurring in cells within solid spheres with time-lapse microscopy. To assay for changes in mitochondrial membrane polarization, we employed JC-1 dye, which accumulates in the mitochondria of healthy cells as aggregates (red fluorescence) while the monomeric form in the cytoplasm fluoresces green. Upon onset of apoptosis, the

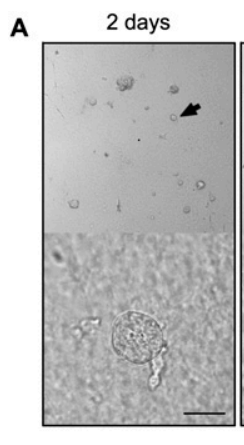

B

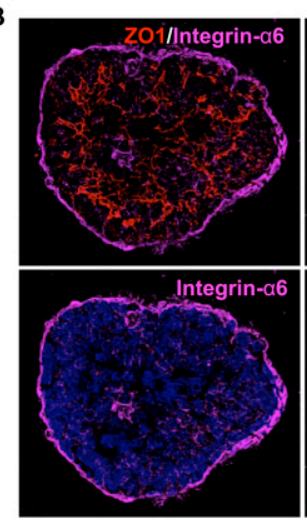

3 days

5 days

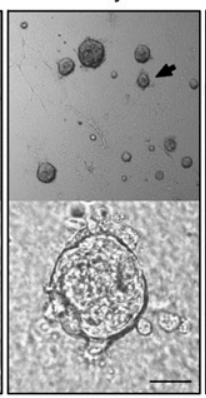

1 day off

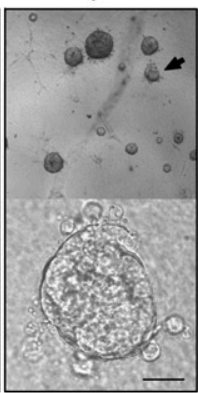

2 days off
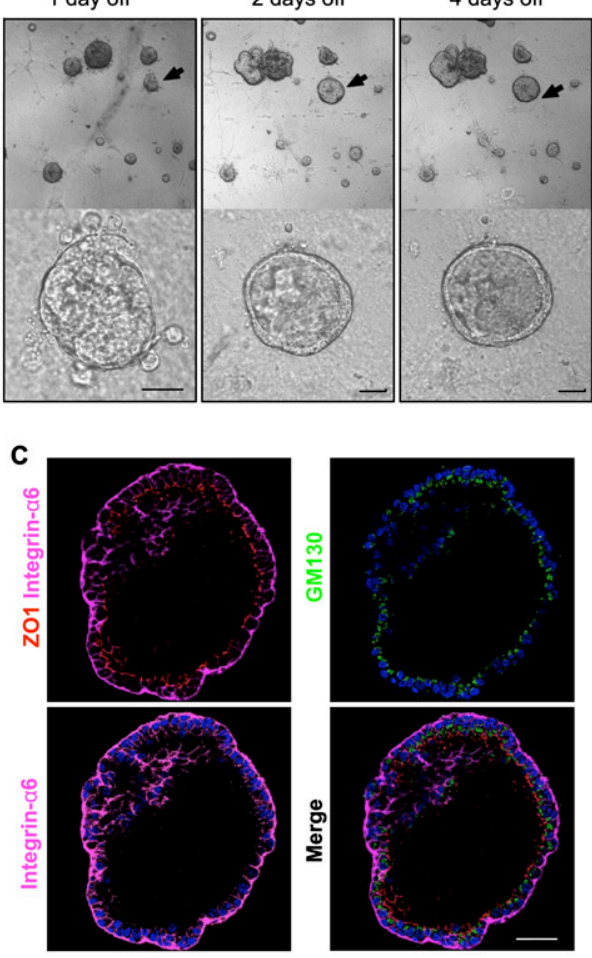

Figure 5. Single tritransgenic cell exposed to a doxycycline form solid, depolarized spheres that regresses to a repolarized rim upon doxycycline withdrawal. (A) Bright-field pictures taken at indicated time points follow a typical field with representative cell aggregates over a time course of $9 \mathrm{~d}$. Doxycycline treatment was started at the single-cell stage $8 \mathrm{~h}$ after seeding cells into the 3D matrix. (Top panels) Pictures show solid growth of aggregates upon doxycycline treatment and clearance of internal cells after doxycycline withdrawal; the arrow indicates the single structure that is shown in the bottom panels. Bar, $30 \mu \mathrm{m}$. (B) Confocal microscopy shows the distribution of markers for epithelial polarity in a typical aggregate grown from a single tritransgenic cell for $4 \mathrm{~d}$ in the presence of doxycycline. A $5-\mu \mathrm{m}$ projection through the middle of the sphere shows several smaller lumina lined by ZO1 staining and otherwise depolarized cells. (Blue) DAPI stain; (green) GM130; (red) ZO1; (magenta) Integrin $\alpha 6$. Bar, $40 \mu \mathrm{m}$. (C) Confocal microscopy shows a typical repolarized single-cell-layered sphere that survives doxycycline withdrawal; $5-\mu \mathrm{m}$ projection through the middle of the sphere that was fixed and stained $5 \mathrm{~d}$ after removal of doxycycline. (Blue) DAPI stain; (green) GM130; (red) ZO-1; (magenta) Integrin $\alpha 6$. Bar, $40 \mu \mathrm{m}$. 
integrity of the mitochondrial membrane is compromised, the JC-1 dye can no longer accumulate in the mitochondria, remains in the cytoplasm, and the red/ green fluorescence intensity ratio is decreased (Smiley et al. 1991). Indeed, we saw loss of mitochondrial potential exclusively in the middle of the solid spheres $20 \mathrm{~h}$ after doxycycline withdrawal (Fig. 6A). Similarly, confocal analyses employing NucView substrate, a cell membrane-permeable fluorogenic (488 nm) substrate cleavable with caspase-3, showed increased caspase-3 activity concurrently with the loss of mitochondrial membrane potential. This effect spread from the center of the solid spheres toward the outer regions, but did not affect the cells directly attached to the matrix (Fig. 6B). These findings suggest that most of the internal cells lose mitochondrial potential following oncogene deinduction, leading to caspase-3-dependent apoptosis.

\section{Cells surviving doxycycline withdrawal exclude} Hoechst dye 33342 and have an increased capacity to reseed cultures and repopulate mammary glands

To seek possible differences between the initially polarized cells in acini formed with uninduced tritransgenic mammary cells and the surviving repolarized singlelayered spheres after deinduction, we stained these two distinct polarized populations with Hoechst 33342. An ability to exclude this dye is a feature of cell populations that are enriched for progenitor cells ("side population" cells) (Welm et al. 2002; Smalley and Clarke 2005). We found that cells from the surviving rim were able to exclude Hoechst 33342 (Fig. 7A, top middle panel), while cells in acini that had never been exposed to doxycycline failed to do so. Cells seen at the surface of solid spheres grown in doxycycline were also able to exclude dye, implying that they are the cells that survive after doxycycline is removed (Fig. 7A, top middle panel and bottom middle panel).

To determine whether BCRP (ABCG2), a transmembrane protein and member of the multidrug resistance (Mdr) family known to pump Hoechst 33342 out of cells, is responsible for dye exclusion, the spheres were grown in the presence of the Mdr inhibitory drug verapamil. As expected, verapamil blocked the ability of cells at the rim to exclude Hoechst 33342. To exclude misleading optical effects caused by differences in the geometry of the cell aggregates, we confirmed our observations with confocal microscopy on 5- $\mu \mathrm{m}$ projections (Fig. 7A, bottom panels). The ability of the surviving cells to exclude Hoechst 33342 seems to be a long-term effect. We exposed the surviving cells to Hoechst 33342 dye 14 d after doxycycline withdrawal, and they were still able to exclude the dye, while cells in spheres that were never exposed to doxycycline and had been in $3 \mathrm{D}$ gels for the same amount of time showed little capacity to exclude the dye (Supplemental Fig. S3).

Because exclusion of Hoechst dye is an indirect and controversial measure of progenitor and stem cell behavior,
A

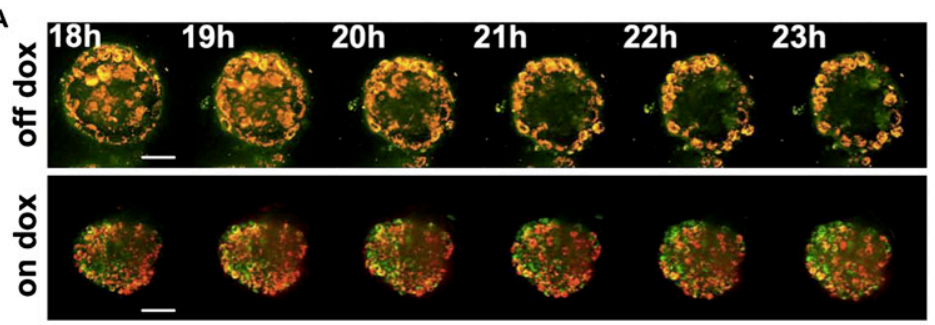

B

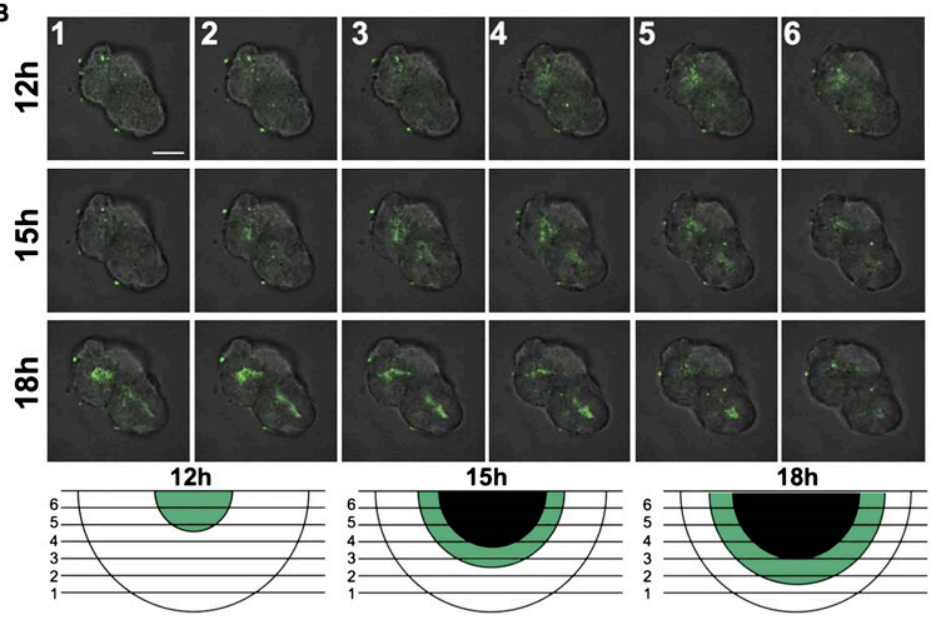

Figure 6. Following doxycycline withdrawal, internal cells lose mitochondrial polarity and undergo Caspase3induced apoptosis. $(A)$ Confocal images of tritransgenic acini grown in the presence of doxycycline for $5 \mathrm{~d}$, then weaned from doxycycline and incubated in MitoProbe JC-1-solution for $1 \mathrm{~h}$ to assess for mitochondrial potential loss during doxycycline withdrawal. The JC-1 dye accumulates in the mitochondria of healthy cells as aggregates (fluorescent red) while the monomeric form in the cytoplasm fluoresces green (yellow overlay). Upon removal of doxycycline, the mitochondrial potential collapses and the JC-1 dye can no longer accumulate in the mitochondria, remains in the cytoplasm, and the red/ green fluorescence intensity ratio is decreased. Projections (covering $10-\mu \mathrm{m}$ depth) through the middle of a typical sphere. (Top panels) JC-1 signal at indicated time points after doxycycline withdrawal. (Bottom panels) JC-1 signal of a control sphere at indicated time points with doxycycline present in the growth media. Bar, $30 \mu \mathrm{m}$. (B) Confocal image of acini grown from tritransgenic cells incubated with NucView substrate for detecting caspase-3 activity within live cells in real time. Established acini were grown in the presence of doxycycline for $5 \mathrm{~d}$ and then weaned from doxycycline. Each row shows six adjacent projections $(5-\mu \mathrm{m}$ depth) that cover the region from the middle of a typical sphere (labeled 6) to the top of the sphere (labeled 1). Caspase3 activity (green fluorescence) is superimposed on the bright-field picture. (Top panels) Caspase-3 activity at 12 $\mathrm{h}$ after doxycycline withdrawal is only seen in the center of layers 6 and 5. (Middle panels) Caspase 3 activity at $15 \mathrm{~h}$ after doxycycline withdrawal is seen in the center of layers 6-3. (Bottom panels) Caspase-3 activity at $18 \mathrm{~h}$ after doxycycline withdrawal is seen in the center of layers 5-1. Graphic sketches depict the caspase3-activated regions for the three time point analyzed. Bar, $30 \mu \mathrm{m}$ 
Figure 7. Cells surviving oncogene withdrawal acquire mammary progenitor cell characteristics. $(A)$ Spheres grown from tritransgenic primary mammary cells were incubated with Hoechst 33342 for $1 \mathrm{~h}$ at indicated time points and monitored for exclusion of dye the next day. (Top panels) Fluorescent microscopy. Acini never exposed to doxycycline for $12 \mathrm{~d}$ retain the Hoechst staining (left panel), while the cells at the rim of spheres treated with doxycycline for $4 \mathrm{~d}$ (left middle panel) as well as cells surviving doxycycline withdrawal $4 \mathrm{~d}$ doxycycline and subsequently weaned for $4 \mathrm{~d}$ from doxycycline; right middle panel) exclude Hoechst 33342. (Right panel) Treatment with verapamil $(50 \mu \mathrm{M})$ blocks the ability to pump out Hoechst. (Bottom panels) Confocal microscopy projections $(5-\mu \mathrm{m}$ depth, 10 optical sections through the middle of a sphere) at the indicated time points show the same results. (Left panel) Acini never exposed to doxycycline for $8 \mathrm{~d}$ retain the Hoechst staining. (Middle panel) Cells at the rim of solid spheres treated with doxycycline for $4 \mathrm{~d}$ exclude Hoechst 33342. (Right panel) Cells at the

A

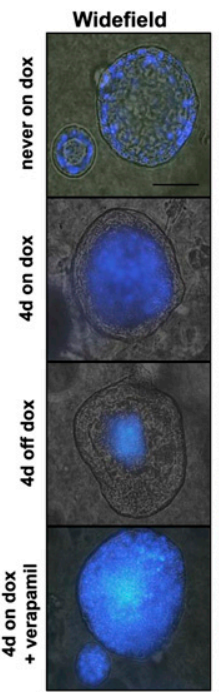

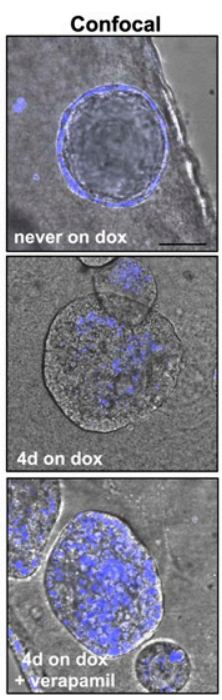

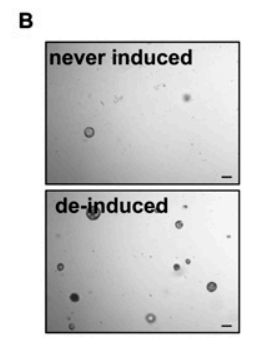
C

D

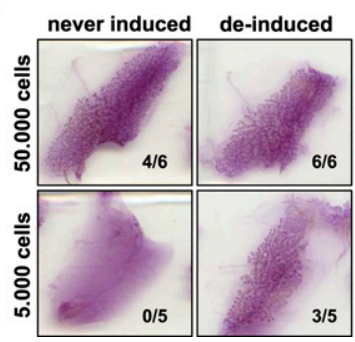

(B) Bright-field pictures show a typical field to compare the reseeding capacity of 1000 cells harvested from tritransgenic spheres that had never been exposed to doxycycline (top panel) versus 1000 cells harvested form surviving spheres after doxycycline withdrawal (bottom panel). Bar, $100 \mu \mathrm{m}$. (C) Bright-field pictures show that acini grown from reseeded cells are still responsive to doxycycline induction. (Top panel) Typical acinus grown from reseeded cells $24 \mathrm{~h}$ after doxycycline induction. (Bottom panel) The same acinus $52 \mathrm{~h}$ after doxycycline induction Bar, $50 \mu \mathrm{m}$. $(D)$ Cells harvested from spheres after doxycycline withdrawal were tested for their capacity to repopulate the cleared mammary fat pad of Rag $1^{-1-}$ mice (right panels) and compared with cells harvested from spheres that were never treated with doxycycline (left panels). Either 50,000 single cells (top panels) or 5000 single cells (bottom panels) were injected from a given population. Inserts indicate numbers of successful engraftments over numbers of injected mammary glands and represent the sum of two independent experiments.

we also tested cells derived from the surviving rim of deinduced cells for expression of the cell surface markers CD24, CD49f, and CD29, which have been associated with cells at early stages in the mammary epithelial lineage (Shackleton et al. 2006; Stingl et al. 2006). Cells derived from the surviving rim were enriched for $\mathrm{Lin}^{-} \mathrm{CD} 29^{\text {hi }} \mathrm{CD} 24^{+}$and $\mathrm{Lin}^{-} \mathrm{CD} 24^{\text {med }}$ CD $49 \mathrm{f}^{\text {high }}$ cells compared with cells derived from acini that had never been exposed to doxycycline (Supplemental Fig. S4).

Finally, we asked whether the dye-excluding "side population" cells displayed functional characteristics of mammary cell progenitors. We compared the ability of cells harvested from uninduced spheres (Fig. 7B, top panel) and cells from the surviving rim of deinduced spheres (Fig. 7B, bottom panel) to form new acini in 3D cultures. Cells from the deinduced spheres were approximately eightfold more likely than cells from uninduced spheres to form new acini (never induced cells: $46 \pm 14$ acini per gel $[N=6]$; deinduced cells: $392 \pm 63$ acini per gel $[N=6])$. Furthermore, secondary acini become solid spheres after re-exposure to doxycycline, indicating that the residual cells retain responsiveness to the original oncogenes (Fig. 7C).

It has been previously demonstrated that at least 100,000 unfractionated mammary epithelial cells must be transplanted into cleared mouse mammary fat pads to guarantee successful outgrowth of a new gland (Smith 1996; Smalley and Clarke 2005). We observed successful engraftment after most injections of $5 \times 10^{4}$ single cells from acini never exposed to doxycycline (four out of six engraftments) (Fig. 7D, left panels), but no engraftment using $5 \times 10^{3}$ of these cells (zero out of five engraftments) (Fig. 7D, bottom left panel). In contrast, in three out of five attempts, $5 \times 10^{3}$ cells harvested from hollow spheres that survived doxycycline withdrawal successfully repopulated the cleared fat pad of Rag $1^{-1-}$ mice (Fig. $7 \mathrm{D}$, bottom right).

Taken together, these findings suggest that we enriched for progenitor cells by deinducing oncogene expression in $3 \mathrm{D}$ cultures of mammary cell aggregates.

\section{Discussion}

Using primary mammary epithelial cells from mice with inducible oncogenic transgenes, we developed a 3D culture system that can be used to study epithelial polarization, cell proliferation, and cell survival in response to oncogene induction and deinduction. In many respects, our findings in cell culture mimic those observed in the mammary glands of TetO-MYC;TetO-Kras ${ }^{G 12 D}$;MMTVrtTA tritransgenic mice from which the cultures are derived. In addition, we identified and isolated cells from this culture system that have survived oncogene withdrawal and exhibit characteristics of mammary gland progenitors.

Under the growth conditions we used, single primary mammary cells are able to form multicellular acinar structures, with a hollow center surrounded by a rim of 
highly polarized epithelial cells (Fig. 1). The process of lumen development appears to be driven by expansion of cells at the surface of the sphere, rather than by death of internal cells: Markers of apoptosis are not observed, and the metaphase plates in dividing cells are oriented perpendicular to the apical surface, allowing growth of the acinus by an enlarging monolayer of epithelial cells (Fig. 2). This process is likely to be directed by Cdc 42 signaling, which specifies the apical surface by controlling spindle orientation (Jaffe et al. 2008). The mechanism by which the lumen is formed could involve fluid accumulation driven by polarized ion transport (Bagnat et al. 2007), intercellular fusion of vacuoles that discharge their contents into the lumen (Kamei et al. 2006), or both, and will require further study. Recent studies of MDCK cells in $3 \mathrm{D}$ culture demonstrates an inverse relationship between the roles of polarization and apoptosis in lumen development (Martin-Belmonte et al. 2008): Apoptosis was not required for lumen formation by polarized MDCK cells, but lumens were formed by apoptosis when polarization was delayed by siRNA against Cdc 42 .

Transgenic mice have been widely employed to study the physiological effects of oncogenes expressed in a wide variety of tissue types. In recent years, the design of such mouse models has often taken advantage of methods-especially tetracycline-dependent transcriptional regulation-that permit temporal as well as lineagespecific control of oncogene expression. These models have revealed important aspects of neoplasia-kinetics of tumor formation, oncogene cooperation, and oncogene dependence, but it has proven difficult to recapitulate some of the most significant phenomena, including regulation of oncogenes, tumor regression, and tumor recurrence, in cultured epithelial cells in a fashion that might permit more detailed mechanistic analysis. Moreover, successful regulation of doxycycline-inducible genes has been reported only rarely using cell lines in 2D conditions (van Nimwegen et al. 2005).

The consequences of oncogenic signaling are commonly measured in immortalized cell lines or primary fibroblasts-grown as monolayers on plastic dishes-that express genes implicated in cancer. To provide growth conditions in vitro that resemble conditions in vivo, a number of well-characterized epithelial lines, most prominently MDCK and MCF10A lines, have been grown in 3D cultures (Schmeichel and Bissell 2003; Debnath and Brugge 2005). Under these conditions, the cells take cues from the basement membrane and polarized neighboring cells and are more likely to exhibit the behavior expected of epithelial cells in an animal. However, successful transformation of a normal appearing organotypic structure to a putative neoplastic phenotype has been reported only rarely; for example, after homo-dimerization of ErbB2 in MCF10A cells (Muthuswamy et al. 2001).

In the studies reported here, we used primary epithelial cells from transgenic mice, rather than established cell lines; we controlled expression of cooperating oncogenes, MYC and mutant Kras, by addition and removal of doxycycline; and we observed dramatic changes in patterns of growth, polarity, and cell death in response to changes in production of oncoproteins. These features of our culture system permit a detailed description of neoplastic events after induction of oncogenes and of the consequences of oncogene deinduction, the latter being a surrogate for optimal targeted therapy of cancers caused by known oncogenes.

Induction of MYC and Kras ${ }^{G 12 D}$ oncogenes in polarized acini (or in single cells at the time of plating) is followed by a loss of epithelial polarity and the formation of solid spheres of epithelial cells (Figs. 4A, 5B), with a dramatic increase in the proliferation index (Fig. 4B). In temporal course and appearance, this process is very similar to what we and others observed when potent oncogenes, including the same combination of MYC and Kras, are induced in the mammary glands of transgenic animals (Fig. 3C; Podsypanina et al. 2008). Moreover, these features are strikingly reminiscent of DCIS, believed to be an early phase of development of common forms of breast cancer in women (Porter et al. 2003; Burstein et al. 2004).

A consistent and important aspect of the system for epithelial cell transformation presented here is the response of 3D aggregates of transformed cells to the deinduction of oncogenes that follows withdrawal of doxycycline. Depolarized, solid spheres, grown from established acini or from single cells in the presence of doxycycline, swiftly regress (Figs. 4E, 5C), with loss of mitochondrial membrane potential and induction of apoptosis (Fig. 6), in a manner that resembles tumor regression in mice that have been placed on a diet that causes loss of expression of oncogenic transgenes (Moody et al. 2002; Gunther et al. 2003; Shachaf et al. 2004; Podsypanina et al. 2008).

An important characteristic of such doxycyclinedependent cancer models is the frequent recurrence of tumors, with varied latencies, but usually with reactivation of one or both of the initiating oncogenes (Chin et al. 1999; Felsher and Bishop 1999; Podsypanina et al. 2008) or with an activating mutation in the same signaling pathway (Debies et al. 2008). Tumor recurrence, without a second round of induction of regulated oncogenes, implies that some of the original tumor cells may survive deinduction of the oncogenes and remain in a latent state until additional events occur to allow tumor regrowth.

Unfortunately, it has been difficult to isolate and characterize such survivors, quiescent cells with high tumorigenic potential, directly from mouse models. In our 3D culture system, we found that a single layer of polarized cells survives doxycycline withdrawal, the down-regulation of oncogenes, and widespread apoptosis within the solid spheres of transformed cells (Figs. 4E, 5C). Although we do not know the mechanism by which these cells survive, repolarize, and gain progenitor-like properties, it is possible that these attributes are dependent, at least in part, on paracrine factors produced by the inner cells before apoptosis. In addition, the placement of transformed cells at the rim of solid spheres-allowing interaction with a basement membrane-may be a deter-minant of cell survival upon doxycycline withdrawal. A similar phenomenon has been observed with human mammary MCF10A cells: Integrin $\beta 1$ signaling and nonmalignant 
EGFR signaling cooperate to repress expression of the proapoptotoic protein Bim to prevent anoikis (Reginato et al. 2003). However, Integrin $\beta 1$ signaling to repress Bim is not needed in conjunction with other potent oncogenes that induce accumulation of cells in the lumens of MCF10A acini (Reginato et al. 2005). Consistent with this observation, inhibition of Integrin $\beta 1$ signaling in the HMT-3522 human mammary cell line caused apoptosis during normal acinar morphogenesis, but not during tumorigenic growth (Howlett et al. 1995).

Cells at the outer surface of solid spheres in our experiments differ from cells in acini that were never exposed to doxycycline, since they, but not the acinar cells, are able to exclude Hoechst 33342 (Fig. 7A). Moreover, cells collected from the surviving rims of deinduced aggregates have an enhanced potential to reform acini in 3D culture (Fig. 7B) and to repopulate cleared fat pads with mammary glands (Fig. 7D). This suggests that MYC and mutant Kras collaborate with signals from the basement membrane, likely mediated through integrins, to reprogram cells toward a progenitor phenotype. These cells appear to resist entering the apoptotic cascade upon down-regulation of oncogenes, allowing them to become the putative precursors of recurrent tumors. Our ability to recover such cells from the $3 \mathrm{D}$ cultures we described here should now permit a much more extensive characterization of the properties and fates of the surviving cells.

\section{Materials and methods}

\section{Materials}

3D Culture Matrix Basement Membrane Extract (Cat\# 3445-04801) and Rat Collagen I (Cat\#3447-020-01) were purchased from Trevigen Inc. Anti-E-Cadherin (Cat\#610182) and anti-GM130 (Cat\#610823) antibodies were purchased from BD Transduction Laboratories, anti-ZO1 antibody from Zymed Laboratories, Inc. (catalog nu. 61-7300), anti-Integrin $\alpha 6$ antibody from Chemicon International, Inc. (MAB1378), anti-aPKC antibody from Santa Cruz Biotechnologies, Inc. (catalog no. sc-216), and anti- $\beta$-tubulin and $\gamma$-tubulin antibodies from Sigma-Aldrich (catalog nos. T5293 and T4026). Anti-rabbit, anti-mouse, and anti-rat antibodies were purchased coupled with Alexa Fluor dyes from Invitrogen/Molecular Probes (catalog nos. A11006, A11029, A11034, A11037, A11032, A21247). Verapamil hydrochloride (catalog no. V4629) and Doxycycline hydrochloride (catalog no. VD98914629) were purchased from Sigma-Aldrich.

\section{Preparation of mammary cells for morphogenesis assay}

The tissue from two mammary glands without mechanical dissociation was placed in 5-mL digestion medium (DMEM/ F12 with L-glutamine, $15 \mathrm{mM}$ HEPES (Biowhittaker, no. 12719Q), supplemented with 1 M HEPES (Biowhittaker, no. 17$737 \mathrm{E}$ ) to $25 \mathrm{mM}$ final concentration, $150 \mathrm{U} / \mathrm{mL}$ Collagenase type 3 (Worthington, no. CLS3), and $20 \mu \mathrm{g} / \mathrm{mLLiberase}$ Blendzyme 2 (Roche, no. 11988425001), and digested for $15-16 \mathrm{~h}$ at $37^{\circ} \mathrm{C}$ in loosely capped $50-\mathrm{mL}$ polypropylene conical tubes. The resultant organoid suspension was washed with $45 \mathrm{~mL}$ of phosphatebuffered saline (PBS) containing $\mathrm{Ca}^{++}$and $\mathrm{Mg}^{++}$, pelleted at $1000 \mathrm{rpm}$ for $5 \mathrm{~min}$ at room temperature, and resuspended in 5 $\mathrm{mL}$ of $0.25 \%$ trypsin-EDTA. After incubation for $40 \mathrm{~min}$ at $37^{\circ} \mathrm{C}$ in loosely capped 50-mL polypropylene conical tubes, cells were washed with $45 \mathrm{~mL}$ of DMEM/F12 with Lglutamine, $15 \mathrm{mM}$ HEPES, supplemented with $1 \mathrm{M}$ HEPES to $25 \mathrm{mM}$ final concentration and with 10\% Tet System Approved FBS (Clontech, no. 631101). When necessary, suspensions were treated with 5-15 $\mathrm{mg} / \mathrm{mL}$ DNaseI (Sigma, no. D4527). Dissociated cells were pelleted at $1000 \mathrm{rpm}$ for $5 \mathrm{~min}$ at room temperature and resuspended in PBS containing $\mathrm{Ca}^{++}$and $\mathrm{Mg}^{++}$, counted, and plated onto collagen-coated 10-cm plates (BioCoat, \#356450) in preparation for the in vitro morphogenesis assays and injections into the cleared fat pad.

\section{Morphogenesis assay}

One day after plating, cultured cells were washed with PBS without $\mathrm{Ca}^{++}$and $\mathrm{Mg}^{++}$, and the remaining cells were treated with $1 \mathrm{~mL} 0.25 \%$ trypsin-EDTA. After cell detachment, trypsin was inactivated with $9 \mathrm{~mL}$ DMEM/F12 with Lglutamine, $25 \mathrm{mM}$ HEPES, supplemented with 10\% Tet System Approved FBS. Cells were pelleted at $1000 \mathrm{rpm}$ for $5 \mathrm{~min}$ at room temperature and resuspended in PBS containing $\mathrm{Ca}^{++}$and $\mathrm{Mg}^{++}$and counted. Cells were mixed rapidly on ice with "Cultrex 3D Culture Matrix Basement Membrane Extract" containing $1.5 \mathrm{mg} / \mathrm{mL}$ "Cultrex 3D Collagen I rat tail." Droplets $(100 \mu \mathrm{L})$ containing 8000 cells from mammary gland preparations were dispensed into 17-mm wells or chambered coverglass slides. After solidification on a level surface for $30 \mathrm{~min}$ at $37^{\circ} \mathrm{C}$, the gels were placed at $37^{\circ} \mathrm{C}$ in a $\mathrm{CO}_{2}$ incubator with $1.5 \mathrm{~mL}$ of supplemented serumfree medium (Mammary Epithelial Cell Medium BulletKit, \#CC3150, containing one 500-mL bottle of Mammary Epithelial Cell Basal Medium and supplements: $2 \mathrm{~mL}$ of bovine pituitary extract, $0.5 \mathrm{~mL}$ of hEGF, $0.5 \mathrm{~mL}$ of hydrocortisone, $0.5 \mathrm{~mL}$ of GA-1000, $0.5 \mathrm{~mL}$ Insulin, [Cambrex]) that contained $1 \mu \mathrm{g} / \mathrm{mL}$ doxycycline when indicated. Media was replaced every $2 \mathrm{~d}$.

Details about animal husbandry, genotyping, and transgene expression studies; histology and whole-mount preperation; mammary fat pad repopulation assay; FACS analyses; and immunofluroscence analysis can be found in the Supplemental Material.

\section{Acknowledgments}

We thank M.A. Melnick, G. Sanchez, and A. Giannakou for expert handling of the mouse colony; A. Hall for discussions and critical input; L. Beverly for help with the FACS analysis and assembly of Supplemental Figure S4; K. Manova and Z. Lazar for assistance with confocal analysis; J. Gardner for help with the JC-1 assay; R. Sotillo and J.M. Schvartzman for critically reading the manuscript and assistance with graphical work; and A. Ventura, F. Asimakopoulos, L. Beverly, and A. Unni for critically reading the manuscript. This work was supported by the U.S. Department of Defense (W81XWH-05-1-0220 to M.J.), the Life Sciences Research Foundation (Lilly Research Laboratories Fellow 2004 to M.J.), the NIH (K01 CA118731 to K.P., P01 CA94060 to H.V., and R24 CA83084 and P30-CA 08748, for core facilities), and the Martell Foundation (to H.V.).

\section{References}

Bagnat M, Cheung ID, Mostov KE, Stainier DY. 2007. Genetic control of single lumen formation in the zebrafish gut. Nat Cell Biol 9: 954-960.

Barcellos-Hoff MH, Aggeler J, Ram TG, Bissell MJ. 1989. Functional differentiation and alveolar morphogenesis of 
primary mammary cultures on reconstituted basement membrane. Development 105: 223-235.

Bissell MJ, Radisky D. 2001. Putting tumours in context. Nat Rev Cancer 1: 46-54.

Burstein HJ, Polyak K, Wong JS, Lester SC, Kaelin CM. 2004. Ductal carcinoma in situ of the breast. $N$ Engl I Med 350: 1430-1441.

Chin L, Tam A, Pomerantz J, Wong M, Holash J, Bardeesy N, Shen Q, O'Hagan R, Pantginis J, Zhou H, et al. 1999. Essential role for oncogenic Ras in tumour maintenance. Nature 400: 468-472.

Debies MT, Gestl SA, Mathers JL, Mikse OR, Leonard TL, Moody SE, Chodosh LA, Cardiff RD, Gunther EJ. 2008. Tumor escape in a Wnt1-dependent mouse breast cancer model is enabled by p19Arf/p53 pathway lesions but not p16 Ink4a loss. J Clin Invest 118: 51-63.

Debnath J, Brugge JS. 2005. Modelling glandular epithelial cancers in three-dimensional cultures. Nat Rev Cancer 5: 675-688.

Debnath J, Mills KR, Collins NL, Reginato MJ, Muthuswamy SK, Brugge JS. 2002. The role of apoptosis in creating and maintaining luminal space within normal and oncogeneexpressing mammary acini. Cell 111: 29-40.

Druker BJ, Talpaz M, Resta DJ, Peng B, Buchdunger E, Ford JM, Lydon NB, Kantariian H, Capdeville R, Ohno-Jones S, et al. 2001. Efficacy and safety of a specific inhibitor of the BCRABL tyrosine kinase in chronic myeloid leukemia. $N$ Engl $J$ Med 344: 1031-1037.

Felsher DW, Bishop JM. 1999. Reversible tumorigenesis by MYC in hematopoietic lineages. Mol Cell 4: 199-207.

Fisher GH, Wellen SL, Klimstra D, Lenczowski JM, Tichelaar JW, Lizak MJ, Whitsett JA, Koretsky A, Varmus HE. 2001. Induction and apoptotic regression of lung adenocarcinomas by regulation of a K-Ras transgene in the presence and absence of tumor suppressor genes. Genes \& Dev 15: 32493262.

Fleming ES, Zajac M, Moschenross DM, Montrose DC, Rosenberg DW, Cowan AE, Tirnauer JS. 2007. Planar spindle orientation and asymmetric cytokinesis in the mouse small intestine. J Histochem Cytochem 55: 1173-1180.

Grunert S, Jechlinger M, Beug H. 2003. Diverse cellular and molecular mechanisms contribute to epithelial plasticity and metastasis. Nat Rev Mol Cell Biol 4: 657-665.

Gudjonsson T, Rønnov-Jessen L, Villadsen R, Rank F, Bissell MJ, Petersen OW. 2002. Normal and tumor-derived myoepithelial cells differ in their ability to interact with luminal breast epithelial cells for polarity and basement membrane deposition. J Cell Sci 115: 39-50.

Gunther EJ, Moody SE, Belka GK, Hahn KT, Innocent N, Dugan KD, Cardiff RD, Chodosh LA. 2003. Impact of p53 loss on reversal and recurrence of conditional Wnt-induced tumorigenesis. Genes \& Dev 17: 488-501.

Hall HG, Farson DA, Bissell MJ. 1982. Lumen formation by epithelial cell lines in response to collagen overlay: A morphogenetic model in culture. Proc Natl Acad Sci 79: 4672-4676.

Hamamoto S, Imagawa W, Yang J, Nandi S. 1988. Morphogenesis of mouse mammary epithelial cells growing within collagen gels: Ultrastructural and immunocytochemical characterization. Cell Differ 22: 191-201.

Howlett AR, Bailey N, Damsky C, Petersen OW, Bissell MJ. 1995. Cellular growth and survival are mediated by $\beta 1$ integrins in normal human breast epithelium but not in breast carcinoma. J Cell Sci 108: 1945-1957.

Husain N, Pellikka M, Hong H, Klimentova T, Choe KM, Clandinin TR, Tepass U. 2006. The agrin/perlecan-related protein eyes shut is essential for epithelial lumen formation in the Drosophila retina. Dev Cell 11: 483-493.

Izumi Y, Hirose T, Tamai Y, Hirai S, Nagashima Y, Fujimoto T, Tabuse Y, Kemphues KJ, Ohno S. 1998. An atypical PKC directly associates and colocalizes at the epithelial tight junction with ASIP, a mammalian homologue of Caenorhabditis elegans polarity protein PAR-3. J Cell Biol 143: 95-106.

Jaffe AB, Kaji N, Durgan J, Hall A. 2008. Cdc42 controls spindle orientation to position the apical surface during epithelial morphogenesis. J Cell Biol 183: 625-633.

Kamei M, Saunders WB, Bayless KJ, Dye L, Davis GE, Weinstein BM. 2006. Endothelial tubes assemble from intracellular vacuoles in vivo. Nature 442: 453-456.

Lowery LA, Sive H. 2005. Initial formation of zebrafish brain ventricles occurs independently of circulation and requires the nagie oko and snakehead/atplala.1 gene products. Development 132: 2057-2067.

Martin-Belmonte F, Yu W, Rodriguez-Fraticelli AE, Ewald AJ, Werb Z, Alonso MA, Mostov K. 2008. Cell-polarity dynamics controls the mechanism of lumen formation in epithelial morphogenesis. Curr Biol 18: 507-513.

Montesano R, Schaller G, Orci L. 1991. Induction of epithelial tubular morphogenesis in vitro by fibroblast-derived soluble factors. Cell 66: 697-711.

Moody SE, Sarkisian CJ, Hahn KT, Gunther EJ, Pickup S, Dugan $\mathrm{KD}$, Innocent $\mathrm{N}$, Cardiff RD, Schnall MD, Chodosh LA. 2002. Conditional activation of $\mathrm{Neu}$ in the mammary epithelium of transgenic mice results in reversible pulmonary metastasis. Cancer Cell 2: 451-461.

Muthuswamy SK, Li D, Lelievre S, Bissell MJ, Brugge JS. 2001. ErbB2, but not ErbB1, reinitiates proliferation and induces luminal repopulation in epithelial acini. Nat Cell Biol 3: 785-792.

Pearson GW, Hunter T. 2007. Real-time imaging reveals that noninvasive mammary epithelial acini can contain motile cells. J Cell Biol 179: 1555-1567.

Petersen OW, Ronnov-Jessen L, Howlett AR, Bissell MJ. 1992. Interaction with basement membrane serves to rapidly distinguish growth and differentiation pattern of normal and malignant human breast epithelial cells. Proc Natl Acad Sci 89: 9064-9068.

Podsypanina K, Politi K, Beverly LJ, Varmus HE. 2008. Oncogene cooperation in tumor maintenance and tumor recurrence in mouse mammary tumors induced by Myc and mutant Kras. Proc Natl Acad Sci 105: 5242-5247.

Porter D, Lahti-Domenici J, Keshaviah A, Bae YK, Argani P, Marks J, Richardson A, Cooper A, Strausberg R, Riggins GJ, et al. 2003. Molecular markers in ductal carcinoma in situ of the breast. Mol Cancer Res 1: 362-375.

Reginato MJ, Mills KR, Paulus JK, Lynch DK, Sgroi DC, Debnath J, Muthuswamy SK, Brugge JS. 2003. Integrins and EGFR coordinately regulate the pro-apoptotic protein Bim to prevent anoikis. Nat Cell Biol 5: 733-740.

Reginato MJ, Mills KR, Becker EB, Lynch DK, Bonni A, Muthuswamy SK, Brugge JS. 2005. Bim regulation of lumen formation in cultured mammary epithelial acini is targeted by oncogenes. Mol Cell Biol 25: 4591-4601.

Reichmann E, Ball R, Groner B, Friis RR. 1989. New mammary epithelial and fibroblastic cell clones in coculture form structures competent to differentiate functionally. J Cell Biol 108: $1127-1138$.

Reichmann E, Schwarz H, Deiner EM, Leitner I, Eilers M, Berger J, Busslinger M, Beug H. 1992. Activation of an inducible c-FosER fusion protein causes loss of epithelial polarity and triggers epithelial-fibroblastoid cell conversion. Cell 71: 1103-1116. 
Jechlinger et al.

Schmeichel KL, Bissell MJ. 2003. Modeling tissue-specific signaling and organ function in three dimensions. J Cell Sci 116: 2377-2388.

Shachaf CM, Kopelman AM, Arvanitis C, Karlsson A, Beer S, Mandl S, Bachmann MH, Borowsky AD, Ruebner B, Cardiff $\mathrm{RD}$, et al. 2004. MYC inactivation uncovers pluripotent differentiation and tumour dormancy in hepatocellular cancer. Nature 431: 1112-1117.

Shackleton M, Vaillant F, Simpson KJ, Stingl J, Smyth GK, Asselin-Labat ML, Wu L, Lindeman GJ, Visvader JE. 2006. Generation of a functional mammary gland from a single stem cell. Nature 439: $84-88$.

Smalley MJ, Clarke RB. 2005. The mammary gland 'side population': A putative stem/progenitor cell marker? J Mammary Gland Biol Neoplasia 10: 37-47.

Smiley ST, Reers M, Mottola-Hartshorn C, Lin M, Chen A, Smith TW, Steele GD Jr, Chen LB. 1991. Intracellular heterogeneity in mitochondrial membrane potentials revealed by a J-aggregate-forming lipophilic cation JC-1. Proc Natl Acad Sci 88: 3671-3675.

Smith GH. 1996. Experimental mammary epithelial morphogenesis in an in vivo model: Evidence for distinct cellular progenitors of the ductal and lobular phenotype. Breast Cancer Res Treat 39: 21-31.

Soule HD, Maloney TM, Wolman SR, Peterson WD, Brenz R, McGrath CM, Russo J, Pauley RJ, Jones RF, Brooks SC. 1990. Isolation and characterization of a spontaneously immortalized human breast epithelial cell line, MCF-10. Cancer Res 50: 6075-6086.

Stingl J, Eirew P, Ricketson I, Shackleton M, Vaillant F, Choi D, Li HI, Eaves CJ. 2006. Purification and unique properties of mammary epithelial stem cells. Nature 439: 993-997.

Tsarouhas V, Senti KA, Jayaram SA, Tiklova K, Hemphala J, Adler J, Samakovlis C. 2007. Sequential pulses of apical epithelial secretion and endocytosis drive airway maturation in Drosophila. Dev Cell 13: 214-225.

van Nimwegen MJ, Verkoeijen S, van Buren L, Burg D, van de Water B. 2005. Requirement for focal adhesion kinase in the early phase of mammary adenocarcinoma lung metastasis formation. Cancer Res 65: 4698-4706.

Varmus H, Pao W, Politi K, Podsypanina K, Du YC. 2005. Oncogenes come of age. Cold Spring Harb Symp Quant Biol 70: $1-9$.

Weaver VM, Howlett AR, Langton-Webster B, Petersen OW, Bissell MJ. 1995. The development of a functionally relevant cell culture model of progressive human breast cancer. Semin Cancer Biol 6: 175-184.

Weinstein IB. 2002. Cancer. Addiction to oncogenes-The Achilles heal of cancer. Science 297: 63-64.

Welm BE, Tepera SB, Venezia T, Graubert TA, Rosen JM, Goodell MA. 2002. Sca-1(pos) cells in the mouse mammary gland represent an enriched progenitor cell population. Dev Biol 245: 42-56. 


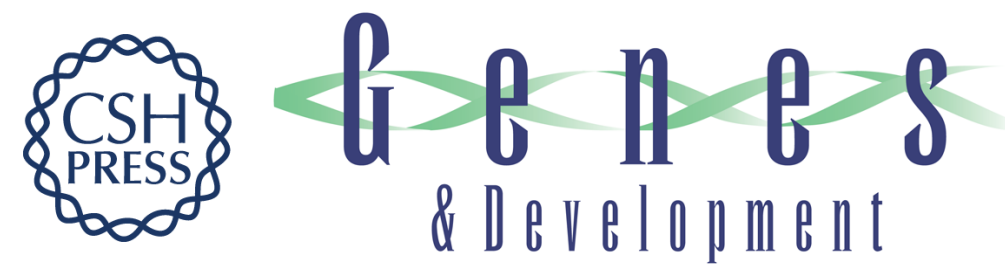

\section{Regulation of transgenes in three-dimensional cultures of primary mouse mammary cells demonstrates oncogene dependence and identifies cells that survive deinduction}

Martin Jechlinger, Katrina Podsypanina and Harold Varmus

Genes Dev. 2009, 23:

Access the most recent version at doi:10.1101/gad.1801809

Supplemental http://genesdev.cshlp.org/content/suppl/2009/07/01/23.14.1677.DC1

Material

References This article cites 49 articles, 21 of which can be accessed free at:

http://genesdev.cshlp.org/content/23/14/1677.full.html\#ref-list-1

License

Email Alerting Receive free email alerts when new articles cite this article - sign up in the box at the top

Service right corner of the article or click here.

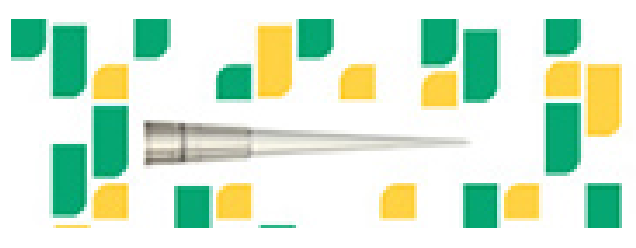

Focused on your science. 